\title{
Native clams facilitate invasive species in an eelgrass bed
}

\author{
Laura F. White ${ }^{1,2, *}$, Lindsay C. Orr ${ }^{2,3}$ \\ ${ }^{1}$ Department of Zoology, University of British Columbia, 6270 University Blvd., Vancouver, British Columbia V6T 1Z4, \\ Canada \\ ${ }^{2}$ Bamfield Marine Sciences Centre, 100 Pachena Road, Bamfield, British Columbia V0R 1B0, Canada \\ ${ }^{3}$ Department of Biology, University of Victoria, Victoria, British Columbia V8W 2Y2, Canada
}

\begin{abstract}
Whether the non-native seaweed Sargassum muticum can displace or impact native eelgrass Zostera marina has been debated in the literature, based on differing substrate requirements of the 2 species. Field observations in Bamfield, British Columbia, Canada, revealed that the non-native S. muticum successfully inhabits an eelgrass bed through colonizing siphons of the native clam Tresus capax. Numerical or physical facilitation of $S$. muticum into the eelgrass bed by $T$. capax may be tempered by seaweed quality or condition. We used field sampling to investigate whether seaweed condition differs between 2 attachment substrates (clam siphon and rock) as a proxy for habitat quality. Attachment substrate promoted different morphologies of $S$. muticum; individuals attached to clam siphons expressed morphologies consistent with sheltered areas compared to individuals attached to rock, which expressed wave-exposed morphologies. Habitat association with the different morphologies supported differences in the epibiont communities colonizing S. muticum. Further, S. muticum subsequently facilitated incursion of the non-native tunicates Styela clava and Botrylloides violaceous into the eelgrass bed through habitat provisioning. By facilitating 2 additional invaders, $S$. muticum enhances the level of invasion in the eelgrass bed. This non-native seaweed has the potential to disrupt the persistence of eelgrass in this system.
\end{abstract}

KEY WORDS: Sargassum muticum · Zostera marina $\cdot$ Non-native species $\cdot$ Facilitation $\cdot$ Tresus capax

\section{INTRODUCTION}

Introduced species can change populations, communities, and ecosystems in dramatic ways over relatively short periods of time (Clavero \& Garcia-Berthou 2005, Kappel 2005), and have been strongly linked to losses of biodiversity (Shurin 2000, Stachowicz et al. 2002, Báez \& Collins 2008). Biological invasions in the marine environment have increased dramatically due to a number of vectors promoted by globalization and the increase of transoceanic shipping. The dominant vector for the introduction of non-native marine and estuarine species to the northeast Pacific previously was aquaculture, with imports peaking around the 1950s (Wonham \& Carlton 2005), but currently the emphasis lies with shipping (Fofonoff et al. 2003).
Due to their coastal habitat, eelgrass beds are exposed to high invasion pressure, with the number of reports of introduced species in eelgrass beds globally increasing over recent decades (Williams 2007). Eelgrass beds profoundly influence the physical, chemical, and biological environments in coastal waters (Orth et al. 2006). Eelgrass beds are highly productive and important for sediment deposition, substrate stabilization, benthic oxygen production, as substrate for epiphytic seaweeds and invertebrates, and as nursery grounds for many species of economically important fish and shellfish (Williamson 2006). In British Columbia, Canada, these fish and shellfish include the commercially important Dungeness crab Cancer magister and Pacific herring Clupea pallasi. 
Despite the ecological and environmental importance of eelgrass beds, their decline has been observed in many areas of the world, i.e. Florida Bay in North America (Fourqurean \& Robblee 1999), Japan (Environment Agency of Japan 2000), the European Mediterranean (Marbà et al. 2005), and Australia (Walker et al. 2006). Over the last decade, 90000 ha of eelgrass loss has been documented, although the actual area lost is certainly greater (Short \& WyllieEcheverria 1996). Declines have been attributed to (1) disturbance of coastal and estuarine environments, including industrial, residential, and recreational development, where impacts are most notably manifested in the near-absence of eelgrasses in industrialized ports and areas of intense human coastal development (Short \& Wyllie-Echeverria 1996, Orth et al. 2006), and (2) the incursion of non-native species (Orth et al. 2006, Martínez-Lüscher \& Holmer 2010).

We found the non-native seaweed Sargassum muticum (Yendo) Fensholt (Phaeophyceae: Fucales) colonizing an eelgrass bed at the head of Bamfield Inlet, Bamfield, British Columbia. A non-native seaweed from southeast Asia, Sargassum muticum was accidentally introduced to British Columbia around the 1940s with Japanese oysters Crassostrea gigas that were imported for aquaculture (Scagel 1956). Sargassum muticum is both a fouling species and an opportunist (Critchley 1983). Effective dispersal strategies, which include vegetative drift and the ability to selffertilize, enable Sargassum muticum to colonize nearly any available hard substrate, including rocks in sand and mud substrates, docks, pilings, boat hulls, and other human-made structures, shells, and other seaweeds, from the lower littoral to the sub-littoral (Critchley et al. 1983) - habitat usually occupied by eelgrass. Sargassum muticum has proved to be a preemptive competitor whose effects are not evident initially after its introduction, making it difficult to justify a rapid response to remove it (Williams 2007). Since its introduction to the northeast Pacific, Sargassum muticum has been of particular concern to environmental managers, largely because it has been documented competing with a number of native seaweed taxa: Lithothrix aspergillum (DeWreede \& Vandermeulen 1988), bull kelp Nereocystis luetkeana (Thom \& Hallum 1990), Gracilaria verrucosa, Scytosiphon lomentaria, and the kelps Macrocystis integrifolia (Ribera \& Boudouresque 1995), Laminaria bongardiana, and Agarum spp. (Britton-Simmons 2004).

Whether Sargassum muticum can displace or impact eelgrass has been debated in the literature. Druehl (1973) suggested that $S$. muticum may displace native eelgrass Zostera marina in British Columbia based on observations that the seaweed had become well established in habitat typically occupied by Z. marina. Con- trary to this, a number of empirical studies showed that the 2 species could coexist without interference as $S$. muticum was unable to colonize the soft sediments inhabited by $Z$. marina (North 1973, Fletcher \& Fletcher 1975, Norton 1977, Thomsen et al. 2006). However, den Hartog (1997) and Strong et al. (2006) showed that the 2 species can coexist in mixed substrates when eelgrass is in decline.

In the present study we found the non-native seaweed Sargassum muticum colonizing the distal end of siphons of the clam species Tresus capax. Native to the Pacific Northwest, T. capax is abundant in the low intertidal zone, burying to depths of $1 \mathrm{~m}$ in sand and mud substrates, from the lower littoral down into the sub-littoral, occurring above, in and below Zostera marina. $T$. capax is a filter-feeding bivalve that possesses a long $(\sim 30 \mathrm{~cm})$ fused siphon, extending from the soft sediments into the overlying water column (Coan et al. 2000). The shells are flared around the siphon and individuals are unable to completely close or fully retract their siphons within their shells. At low tide, the extended siphons lie on the surface of the mud, retracting when disturbed and pulling the attached S. muticum down into the substrate. T. capax facilitates incursion of the non-native seaweed into the $Z$. marina bed through habitat provision of a solid substrate for attachment. Despite this, numerical or physical facilitation of non-native $S$. muticum into the eelgrass bed by T. capax may be tempered by seaweed quality or condition. We used field sampling to investigate whether seaweed condition differs between the 2 attachment substrates (T. capax siphon and rock) as a proxy for habitat quality. Specifically we looked at whether any morphological differences in S. muticum were manifested through the attachment substrate, as individuals colonizing a frequently retracting siphon were repeatedly dragged across the mud and partially buried in the sediment. We explored whether the different morphotypes of $S$. muticum expressed as a function of attachment substrate influenced the abundance and composition of the epibiont community colonizing it.

\section{MATERIALS AND METHODS}

Study site. The present study was conducted at Bamfield Marine Sciences Centre (hereinafter BMSC), on the west coast of Vancouver Island, Canada. Bamfield Inlet $\left(48^{\circ} 48.9^{\prime} \mathrm{N}, 125^{\circ} 09.5^{\prime} \mathrm{W}\right)$ is highly sheltered, with low tidal flow. Large expanses of eelgrass Zostera marina colonizing a sandy-mud substrate characterize the lower littoral zone, extending into the sub-littoral zone. The mid-littoral zone is rock-strewn and dominated by the Pacific oyster Crassostrea gigas (introduced for aquaculture from Japan) and the ephemeral 
green seaweed Ulva intestinalis. Non-native Sargassum muticum is sparsely distributed throughout the eelgrass bed, but forms a dense band $\sim 2 \mathrm{~m}$ wide along the upper edge. At this $S$. muticum-Z. marina boundary, rocky substrate for attachment by the non-native seaweed is abundant. Within the eelgrass bed, the substrate is primarily soft sediments, with small rocks and shell fragments patchily dispersed throughout.

Populations of non-native $S$. muticum were surveyed during low tides in July 2008. Sampling was restricted to the $S$. muticum- $Z$. marina boundary to minimize disturbance to the eelgrass bed.

Morphometric comparisons. To determine whether morphological differences exist between Sargassum muticum individuals colonizing the siphons of Tresus capax and those colonizing rock substrates, we established a $30 \mathrm{~m}$ transect along the $S$. muticum-Zostera marina boundary during low tide, and randomly sampled S. muticum individuals along its length. For each individual, we noted the attachment substrate (clam siphon or rock), and measured a number of morphometric characteristics including (A) the length of the longest primary lateral (from the base of the holdfast to the distal tip), (B) the holdfast diameter, (C) the length and (D) the width of the basal axes, (E) the number of primary laterals from the holdfast, and $(F)$ the number of air vesicles on the first branch from the base (Fig. 1). All S. muticum individuals attached to T. capax siphons were located within the top $5 \mathrm{~cm}$ of the siphon.

We collected 44 Sargassum muticum individuals: 22 attached to Tresus capax siphons, and 22 attached to rock substrate. These were individually bagged and transported to BMSC for quantification of the epibiont communities.

Epibionts on non-native Sargassum muticum. We quantified and compared the abundance of all epibionts (native and exotic) on Sargassum muticum individuals attached to the 2 substrates. Each $S$. muticum individual was removed from its collection bag and gently agitated in seawater to dislodge any epifauna. Epibionts were removed from the seaweed using tweezers and identified under a dissecting microscope. Colonial organisms were difficult to quantify in terms of number of individuals, so for the purpose of comparisons between substrate types, we counted each colony as 1 individual.

Statistical analyses. We used principal components analysis (PCA) to view the relationship between the morphology of Sargassum muticum and substrate type. Morphological differences were further explored using separate univariate ANOVAs, as was the relationship between the width and length of the Tresus capax siphon and all of the morphological traits measured on $S$. muticum. We used multivariate ANOVA (MANOVA) to explore whether any distributional differ-

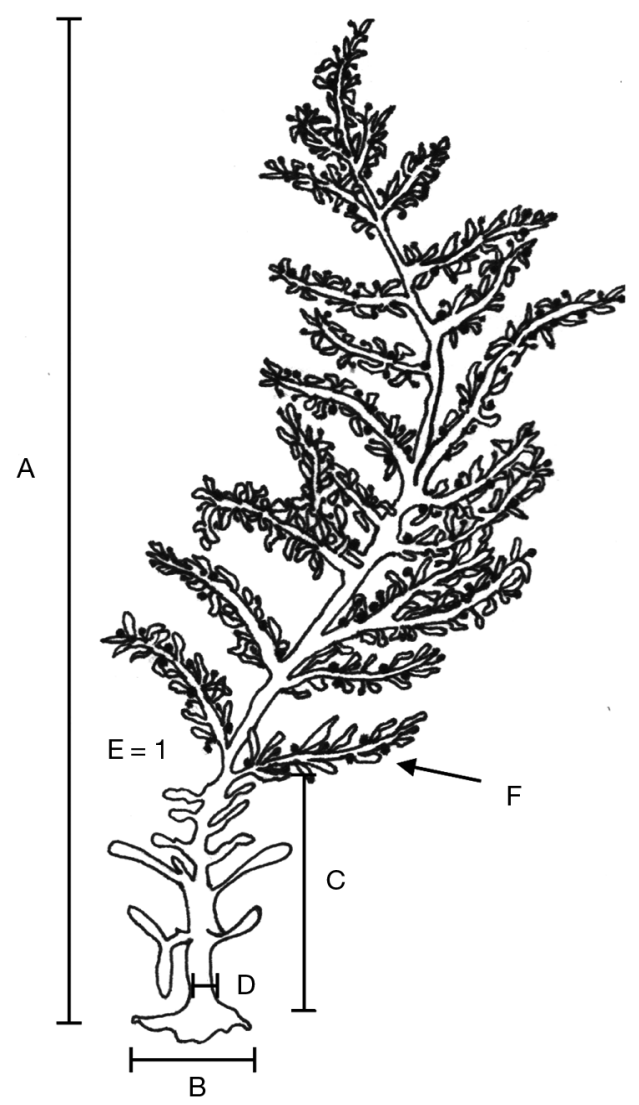

Fig. 1. Sargassum muticum. Morphological traits measured: (A) length of the primary lateral, (B) holdfast diameter, (C) the length and (D) the width of the basal axes, (E) number of primary lateral branches from the holdfast, and (F) number of air vesicles present on the first air branchlet from the base

ences in the epibiont species colonizing S. muticum were promoted by attachment substrate. Individual epibiont species associations were further explored using separate, univariate ANOVAs to indicate the significance of the response by individual species. Data were tested for normality using a Shapiro-Wilk $W$ test, and epibiont abundance data were log-transformed. Epibionts were further separated into mobile and sessile groupings, and analyzed for effects of substrate types using a 2-factor ANOVA. Significant effects were examined using Tukey's HSD. All analyses were performed using JMP 4.0.4 (SAS Institute).

\section{RESULTS}

\section{Morphometric comparisons}

Substrate types were significantly different along the first 2 principal component $(\mathrm{PC})$ axes (ANOVA: PC1: $F_{1,41}=11.99, p=0.001 ;$ PC2: $F_{1,41}=8.49, p=0.006$ ). 
PC1 was largely influenced by the basal portion of the seaweed: (B) the holdfast diameter, (C) the length, and (D) the width of the basal axes, and (F) the number of air vesicles on the first branch from the base. PC2 was influenced by size variables: (A) the length of the longest primary lateral and (E) the number of primary laterals from the holdfast (Table 1). That PC1 and PC2 show significant substrate differences suggests there are morphological differences independent of size. PC3 promoted no substrate differences $\left(F_{1,41}=1.67\right.$, $\mathrm{p}=0.20)$.
To better visualize the response of each morphological trait, we plotted the average morphological response as a function of each substrate type (Fig. 2). Separate ANOVAs revealed that Sargassum muticum individuals attached to Tresus capax siphons were shorter in length $\left(\mathrm{A}_{i} F_{1,42}=7.58, \mathrm{p}=0.009\right)$, and had wider holdfasts $\left(\mathrm{B}_{i} F_{1,42}=20.84, \mathrm{p}<0.0001\right)$, longer basal axes $\left(C_{i} F_{1,42}=5.43, \mathrm{p}=0.02\right)$, and more primary laterals $\left(\mathrm{E}_{;} F_{1,42}=9.77, \mathrm{p}=0.003\right)$ than individuals attached to rocks. No differences were found in the width of the basal axes $\left(D_{;} F_{1,42}=0.12, p=0.73\right)$ or the

Table 1. Principal components analysis (PCA). Variables contributing the greatest to the respective principal component (PC) axis are shown in bold

\begin{tabular}{|c|c|c|c|c|c|}
\hline \multirow{2}{*}{ Variable } & \multicolumn{5}{|c|}{$-\mathrm{PC}$ axis } \\
\hline & 1 & 2 & 3 & 4 & 5 \\
\hline (A) length of longest primary lateral & 0.029 & -0.572 & 0.743 & -0.129 & -0.176 \\
\hline (B) holdfast diameter & 0.548 & 0.090 & 0.217 & -0.027 & -0.364 \\
\hline (C) length of basal axes & 0.452 & 0.315 & 0.126 & -0.667 & 0.427 \\
\hline (D) width of basal axes & 0.449 & -0.376 & -0.048 & 0.502 & 0.632 \\
\hline (E) number of primary laterals from holdfast & -0.123 & 0.637 & 0.587 & 0.452 & 0.158 \\
\hline (F) number of air vesicles on first branch from base & 0.528 & 0.137 & -0.196 & 0.284 & -0.480 \\
\hline Eigenvalue & 1.97 & 1.10 & 1.03 & 0.74 & 0.65 \\
\hline$\%$ Variance & 32.84 & 18.25 & 17.23 & 12.27 & 10.77 \\
\hline
\end{tabular}
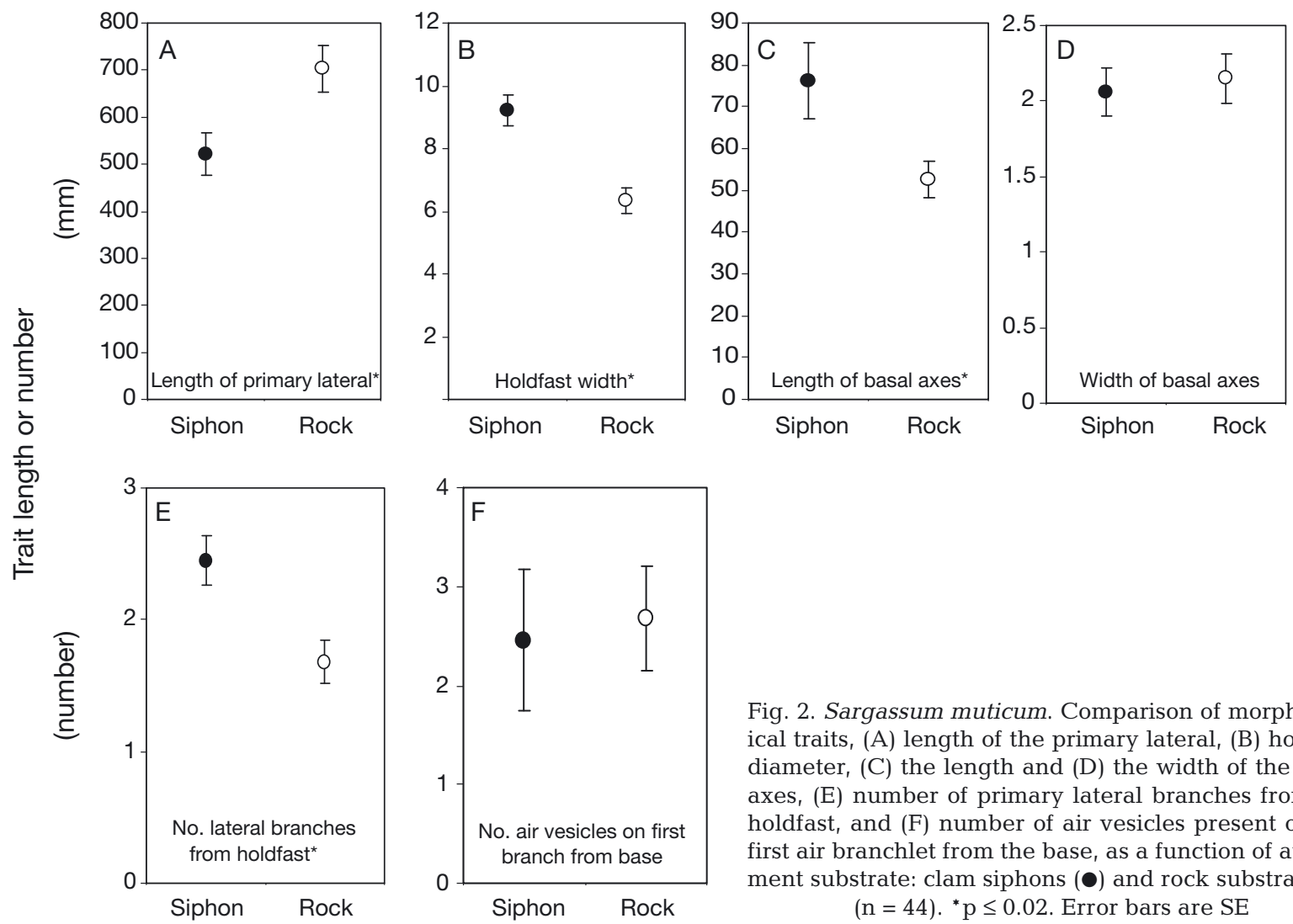

Fig. 2. Sargassum muticum. Comparison of morphological traits, (A) length of the primary lateral, (B) holdfast diameter, (C) the length and (D) the width of the basal axes, (E) number of primary lateral branches from the holdfast, and (F) number of air vesicles present on the first air branchlet from the base, as a function of attachment substrate: clam siphons $(\bullet)$ and rock substrate (O) $(\mathrm{n}=44) .{ }^{*} \mathrm{p} \leq 0.02$. Error bars are SE 
number of air vesicles on the first branch from the base $\left(F_{;} F_{1,42}=0.07, p=0.80\right)$. No relationship existed between the width or length of the $T$. capax siphon, and any of the morphological traits measured (ANOVAs: all $\mathrm{p}>0.11)$. In addition to the 2 substrates we tested, 2 small $(<13 \mathrm{~cm}) S$. muticum individuals were found attached directly to the soft sediments that Zostera marina colonize. The lack of large $S$. muticum individuals attached to the soft sediment might suggest a size threshold, in which the seaweed becomes too large, or the drag created too great, to persist attached to this substrate.

\section{Exotic facilitation}

We found 2 invasive tunicate species, the colonial tunicate Botrylloides violaceus (Code 16 in Table 2) and the solitary tunicate Styela clava (Code 17), colonizing Sargassum muticum attached to Tresus capax siphons within the eelgrass bed. Neither tunicate species was found colonizing the eelgrass directly. Seventeen epibiont species from 8 phyla were found colonizing Sargassum muticum, 4 of which were epiphytic seaweeds (Table 2). All Sargassum muticum individuals sampled hosted $>4$ epibiont species, the most prevalent being the beach hopper amphipod Traskorchestia traskiana (Code 2) and juveniles of the blue mussel Mytilus edulis complex (Code 8).

There was a higher total abundance of epibionts on Sargassum muticum attached to rock than to Tresus

Table 2. Epibiont species found on Sargassum muticum and mobility groupings. n.a. = not avilable

\begin{tabular}{|llll|}
\hline \multirow{2}{*}{ Code } & Species & Common name & Mobility \\
\hline Invertebrates & & & \\
1 & Idotea wosnesenskii & Kelp isopod & Mobile \\
2 & Traskorchestia traskiana & Beach hopper amphipod & Mobile \\
3 & Lottia pelta & Shield limpet & Mobile \\
4 & Littorina sitkanay & Sitka periwinkle & Mobile \\
5 & Littorina scutulata & Checkered periwinkle & Mobile \\
6 & Asterina miniata & Bat star & Mobile \\
7 & Unidentified polychaete & n.a. & Mobile \\
8 & Mytilus edulis complex & Blue mussel & Sessile \\
9 & Membranipora serrilamella & Kelp lace bryozoan & Sessile \\
10 & Spirorbinae spp. & n.a. & Sessile \\
Seaweeds & & & \\
11 & Polyneura latissima & n.a. & Sessile \\
12 & Gracilaria sp. & n.a. & Sessile \\
13 & Ceramium sp. & n.a. & Sessile \\
14 & Ulva intestinalis & Gut weed & Sessile \\
Tunicates & & & Sessile \\
15 & Corella inflata & Transparent tunicate & Sessile \\
16 & Botrylloides violaceus & Violet tunicate (exotic) & Sessile \\
17 & Styela clava & Club tunicate (exotic) & S \\
\end{tabular}

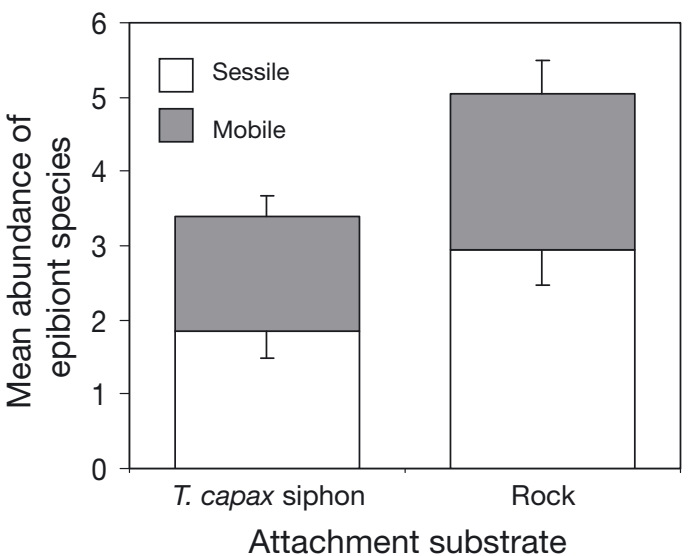

Fig. 3. Mean abundance of mobile and sessile epibiont species by attachment substrate (Tresus capax siphon or rock) of host seaweed Sargassum muticum. Error bars are SE. Epibiont species are presented in Table 2

capax siphons (2-factor ANOVA, substrate $\times$ epibiont species: $\left.F_{33,680}=26.31, \mathrm{p}<0.0001\right)$. We found distributional differences of the epibiont species on Sargassum muticum with substrate type (MANOVA: $F_{1,698}=22.40$, $\mathrm{p}<0.0001$ ). When analyzed separately with individual ANOVAs, only 4 epibiont species showed significant differences in abundance with substrate type. Sargassum muticum attached to rock substrate had higher abundances of the 2 periwinkle species Littorina sitkana (Code $4 ; F_{1,42}=5.45, \mathrm{p}=0.02$ ) and L. scutulata (Code $5 ; F_{1,42}=5.67, \mathrm{p}=0.02$ ), and the bryozoan Membranipora serrilamella (Code $9_{i} F_{1,42}=$ 7.85, p =0.01; Fig. 3) than Sargassum muticum individuals attached to $T$. capax siphons. The exotic tunicate Styela clava (Code 17) was more prevalent on Sargassum muticum attached to $T$. capax siphons $\left(F_{1,42}=\right.$ 4.19, $\mathrm{p}=0.05$; Fig. 3). All other epibiont species showed no difference with substrate type (all p > 0.09), including the exotic tunicate Botrylloides violaceus $\left(F_{1,40}=0.20, \mathrm{p}=0.66\right)$.

We separated epibiont species based on their mobility (mobile or sessile; Table 2) as sessile species utilize Sargassum muticum as habitat whereas mobile species may incidentally occur there. The abundance of mobile and sessile epibionts varied with substrate (2-factor ANOVA, substrate $\times$ mobility: $F_{3,710}=13.74, \mathrm{p}<$ 0.0001) (Fig. 3). Tukey's post hoc tests revealed a higher abundance of both sessile and mobile epibionts on $S$. $m u$ - 
ticum attached to rock than to Tresus capax siphons (Fig. 3). There was no relationship between the length of $S$. muticum individuals and total abundance of epibiont species $\left(F_{1,42}=1.64, \mathrm{p}=0.21\right)$.

We also found individuals of the non-native dwarf eelgrass species Zostera japonica at the upper fringe of the Z. marina bed. Despite Z. japonica frequently existing at the same sites as native $Z$. marina in the northeast Pacific (Britton-Simmons et al. 2010), this is, to our knowledge, the first reported occurrence of Z. japonica in Barkley Sound.

\section{DISCUSSION}

Because eelgrass systems are in decline in many areas of the world (Short \& Wyllie-Echeverria 1996, Orth et al. 2006, Walker et al. 2006), much effort is being devoted to their conservation and restoration (Fonseca et al. 2000). Over recent decades, the number of reports of introduced species in eelgrass beds has increased (Williams 2007), but the role of introduced species in eelgrass systems has not received much attention, with some notable exceptions (dwarf eelgrass Zostera japonica, the seaweed Caulerpa taxifolia). A number of empirical studies have shown that the non-native seaweed Sargassum muticum and native eelgrass $Z$. marina can coexist without interference due to differing substrate requirements (North 1973, Fletcher \& Fletcher 1975, Norton 1977, Thomsen et al. 2006). The present study demonstrates that $S$. muticum successfully colonized a $Z$. marina bed via a variety of mechanisms: colonizing the mixed substrate within the eelgrass bed (both rock and soft sediment directly), and uniquely, via the siphons of the native clam Tresus capax. Tweedley et al. (2008) reported that introduced $S$. muticum in British waters is also capable of colonizing soft sediments within eelgrass beds, suggesting that eelgrass may actually enhance the colonization of the non-native seaweed by trapping vegetative fragments and providing substrate. However, is the numerical or physical facilitation of non-native $S$. muticum into the eelgrass bed by $T$. capax tempered by seaweed quality or condition?

\section{Effects of attachment Substrate on Sargassum muticum morphology}

Strong phenotypic plasticity has long been recognized as a significant characteristic for colonizing or invasive species (Baker 1965, Parker et al. 2003). Wave exposure is a strong determinant of the shape of Sargassum muticum individuals (DeWreede 1978). Individuals inhabiting sheltered areas tend to be shorter and bushier with more lateral branches than individuals in exposed areas, which have longer, but fewer, lateral branches. In the system we studied, the different attachment substrates (Tresus capax siphon or rock) promoted different morphologies of $S$. muticum. Individuals colonizing the siphons of $T$. capax exhibited morphologies consistent with a sheltered area, being shorter in length but producing more lateral branches when compared to individuals on rock substrate, which attained greater lengths, but had fewer lateral branches (Fig. 2). As all S. muticum individuals sampled inhabited the same sheltered area, the difference in morphologies expressed with attachment substrates are likely due to the movement associated with siphons regularly retracting into the sediment and not exposure per se. The sheltered morphology of $S$. muticum found on T. capax is also expressed in tide pools, where individuals are continuously submerged. It is possible that the increased submergence of $S$. muticum attached to T. capax siphons influences morphology. Finally, S. muticum individuals attached to $T$. capax siphons had a greater holdfast width (Fig. 2), which may be necessary to avoid dislodgement during siphon retraction. While $S$. muticum has the ability to persist in the water column after dislodgement and release of germlings, it lacks the ability to reattach to a substrate (Critchley et al. 1986). This suggests that $S$. muticum individuals colonizing the siphons of T. capax must have attached as germlings, remained attached, and developed into adults on a frequently retracting clam siphon. That the $S$. muticum individuals attached to T. capax were adults also suggests that the occurrence of $S$. muticum in the eelgrass bed is not ephemeral, as $S$. muticum germlings recruit in July in British Columbia (White \& Shurin 2007), meaning that $S$. muticum individuals sampled during the present study were all at least $1 \mathrm{yr}$ old, having persisted over the fall.

\section{Positive interactions between non-native species}

By facilitating the 2 non-native tunicate species Styela clava and Botrylloides violaceus through habitat provision of hard substrate for colonization, non-native Sargassum muticum enhanced the level of invasion in the eelgrass bed. Despite this, exotic epibiont species were still relatively rare, and native species dominated in abundance. Wonham et al. (2005) provided another example of a non-native species, the Asian hornsnail Battilaria attramentaria, facilitating invaders in an eelgrass system through habitat provision of hard substrate.

Distributional differences existed for Styela clava, which was more prevalent on Sargassum muticum 
attached to Tresus capax siphons than to rocks, while no effects of substrate were evident for Botrylloides violaceus. In the system we studied, the non-native tunicates utilized Sargassum muticum exclusively as habitat, and no tunicates were found colonizing the eelgrass directly, although $B$. violaceus is reportedly able to grow directly on Zostera marina (Locke et al. 2007).

In her global review, Williams (2007) reported 13 invasive species in eelgrass beds in the northeast Pacific, which did not include either of the non-native tunicate species (Styela clava or Botrylloides violaceus) found during the present study. Invasive tunicates can alter community structure and eelgrass bed size, largely through habitat alteration and space competition. B. violaceus is a colonial tunicate with a sheet-like morphology, and has been observed overgrowing other sessile organisms, including mussels, barnacles, encrusting bryozoans, and solitary sea squirts (Cohen 2005). S. clava is a solitary tunicate which can grow in dense clumps, with densities attaining $1000 \mathrm{~m}^{-2}$ on the east coast of Canada (DFO 2006). Both invasive tunicate species are serious pests of aquaculture, as they interfere with the settlement of oyster and mussel larvae and compete for space and food with young oysters and mussels (DFO 2006). The positive interactions between these invasive species and the potential for compounded negative effects to this eelgrass system are being investigated and will be reported separately.

In addition to the facilitation of non-native tunicates by Sargassum muticum, a number of native epibiont species utilize this non-native seaweed as habitat (Table 2). S. muticum has been described as housing a rich diversity of mobile invertebrates due to its structural complexity (Giver 1999). A variety of structural forms exist within a single individual: a discoid holdfast, cylindrical and moderately branched axes, mature leaflets that are flattened and relatively narrow, large and obovate basal leaves, and spherical air vesicles (Scagel 1973); together, these provide a structurally complex habitat for a wide variety of epibionts. A higher abundance of epibionts were found on $S$. muticum colonizing rocks than on those attached to Tresus capax siphons (Fig. 3), suggesting that habitat associations with the different morphologies promoted by attachment substrate support different epibiont communities. The higher total abundance of epibionts on $S$. muticum attached to rock than to $T$. capax siphons (Fig. 3) is intuitively correct, as the rock substrate provides a relatively stable substrate for attachment whereas clam siphons are frequently retracted into the sediment; however, $S$. muticum individuals attached to T. capax siphons exhibited shorter, bushier morphologies with more lateral braches, potentially providing more surface area for colonization.
In comparison with other studies, we found relatively few ( $\mathrm{n}=17$ ) epibiont taxa on Sargassum muticum (80 taxa: Withers et al. 1975; 115 taxa: Giver 1999; 82 taxa: Bjærke \& Fredriksen 2003). These studies might suggest that $S$. muticum is a positive addition to the local flora as it increases diversity of invertebrates through its structural complexity. However, within Barkley Sound, a study investigating the invertebrate communities associated with seaweeds revealed a low invertebrate abundance on $S$. muticum compared to native species of comparable morphology and size (Bates 2009).

\section{Possible impacts of Sargassum muticum on eelgrass}

While the impacts of these 3 non-native species (Sargassum muticum, Styela clava, and Botrylloides violaceus) on the eelgrass were beyond the scope of the present study, Sargassum muticum has the potential to disrupt the persistence of eelgrass in this system. The main competitive effects of $S$. muticum are shading and the preemption of space (Britton-Simmons 2006, White \& Shurin 2007). S. muticum has perennial basal axes that persist in a vegetative state over winter and thus is poised to preempt space from eelgrass following any disturbance that results in eelgrass declines or loss, such as habitat fragmentation, eutrophication, disease, or impacts of non-native species. Zostera marina is unable to regain space preempted by S. muticum, a pattern observed in other regions (Critchley et al. 1987, Givernaud et al. 1991, den Hartog 1997). While eelgrass beds are often subject to multiple introduced species, their cumulative effects are virtually unstudied (Williams 2007). The potential for compounded negative effects of multiple invaders to this eelgrass system are currently being investigated.

Acknowledgements. We thank M. Wonham, R. DeWreede, C. Harley, and J. Shurin for revisions to this manuscript, and K. Baglot, C. Feehan, K. Sorochan, and T. Tomek for enthusiastic clam-digging. This study started as a student project in the Biodiversity of Marine Algae summer 2007 course at BMSC by L.C.O., and was funded by a grant from the Pacific Northwest Shell Club to L.F.W.

\section{LITERATURE CITED}

Báez S, Collins SL (2008) Shrub invasion decreases diversity and alters community stability in northern Chihuahuan Desert plant communities. PLoS ONE 3:e2332

Baker HG (1965) Characteristics and modes of origin of weeds. In: Baker HG, Stebbins GL (eds) The genetics of colonizing species. Academic Press, New York, NY, p 147-168

Bates CR (2009) Host taxonomic relatedness and functionalgroup affiliation as predictors of seaweed-invertebrate 
epifaunal associations. Mar Ecol Prog Ser 387:125-136

Bjærke MR, Fredriksen S (2003) Epiphytic macroalgae on the introduced brown seaweed Sargassum muticum (Yendo) Fensholt (Phaeophyceae) in Norway. Sarsia 88:353-364

Britton-Simmons KH (2004) Direct and indirect effects of the introduced alga Sargassum muticum on benthic, subtidal communities of Washington State, USA. Mar Ecol Prog Ser 277:61-78

Britton-Simmons KH (2006) Functional group diversity, resource preemption and the genesis of invasion resistance in a community of marine algae. Oikos 113:395-401

Britton-Simmons KH, Wyllie-Echeverria S, Day EK, Booth KP and others (2010) Distribution and performance of the non-native seagrass Zostera japonica across a tidal height gradient on Shaw Island, Washington. Pac Sci 64:187-198

> Clavero M, Garcia-Berthou E (2005) Invasive species are a leading cause of animal extinctions. Trends Ecol Evol 20: 110

Coan EV, Valentinich-Scott P, Bernard FR (2000) Bivalve seashells of western North America: marine bivalve mollusks from Arctic Alaska to Baja California. Santa Barbara Museum of Natural History, Santa Barbara, CA

Cohen AN (2005) Guide to the exotic species of San Francisco Bay. San Francisco Estuary Institute, Oakland, CA. www.exoticsguide.org

Critchley AT (1983) The establishment and increase of Sargassum muticum (Yendo) Fensholt populations within the Solent area of southern Britain. I. An investigation of the increase in number of population individuals. Bot Mar 26: $539-545$

Critchley AT, Farnham WF, Morrell SL (1983) A chronology of new European sites of attachment for the invasive brown alga, Sargassum muticum, 1973-1981. J Mar Biol Assoc UK 63:799-811

Critchley AT, Farnham WF, Morrell SL (1986) An account of the attempted control of an introduced marine alga, Sargassum muticum, in Southern England. Biol Conserv 35: 313-332

- Critchley AT, Nienhuis PH, Verschuure K (1987) Presence and development of populations of the introduced brown alga Sargassum muticum in the southwest Netherlands. Hydrobiologia 151-152:245-255

den Hartog C (1997) Is Sargassum muticum a threat to eelgrass beds? Aquat Bot 58:37-41

DeWreede RE (1978) Phenology of Sargassum muticum in the Strait of Georgia, British Columbia, Canada. Syesis 11:1-9

> DeWreede RE, Vandermeulen H (1988) Lithothrix aspergillum (Rhodophyta): regrowth and interaction with Sargassum muticum (Phaeophyta) and Neorhodomela larix (Rhodophyta). Phycologia 27:469-476

DFO (2006) Invasive species in Northumberland Strait. Fisheries and Oceans Canada, Ottawa. www.dfo-mpo.gc.ca

Druehl LD (1973) Marine transplantations. Science 179:12

Environment Agency of Japan (2000) Threatened wildlife of Japan: red data book, 2nd edn, Vol 8. Vascular plants. Japan Wildlife Research Center, Tokyo

Fletcher RL, Fletcher SM (1975) Studies on the recently introduced brown alga Sargassum muticum (Yendo) Fensholt. I. Ecology and reproduction. Bot Mar 18:149-156

Fofonoff PW, Ruiz GM, Steves B, Carlyon JT (2003) In ships or on ships? Mechanisms of transfer and invasion of non-native species to the coasts of North America. In: Ruiz GM, Carlton JT (eds) Invasive species: vectors and management strategies. Island Press, Washington, DC, p 152-182

Fonseca MS, Kenworthy WJ, Whitfield PE (2000) Temporal dynamics of seagrass landscapes: a preliminary compari- son of chronic and extreme disturbance events. Biol Mar Mediterr 7:373-376

Fourqurean JW, Robblee MB (1999) Florida Bay: a recent history of ecological changes. Estuaries 22:345-357

Giver KJ (1999) Effects of the invasive seaweed Sargassum muticum on native marine communities in northern Puget Sound, Washington. MS thesis, Western Washington University, Bellingham, WA

Givernaud T, Cosson J, Givernaud-Mouradi A (1991) Etude des populations de Sargassum muticum (Yendo) Fensholt sur les côtes de Basse-Normandie (France). In: Elliott M, Ducrotoy JP (eds) Estuaries and coasts: spatial and temporal intercomparisons. ECSA 19 Symposium, Caen, September 1989. Olsen \& Olsen, for Estuarine and Coastal Sciences Association (International Symposium Series No. 19), Fredensborg, p 129-132

Kappel CV (2005) Losing pieces of the puzzle: threats to marine, estuarine and diadromous species. Front Ecol Environ 3:275-282

> Locke A, Hanson JM, Ellis KM, Thompson J, Rochette R (2007) Invasion of the southern Gulf of St. Lawrence by the clubbed tunicate (Styela clava Herdman): potential mechanisms for invasions of Prince Edward Island estuaries. J Exp Mar Biol Ecol 342:69-77

> Marbà N, Duarte CM, Díaz-Almela E, Terrados J and others (2005) Direct evidence of imbalanced seagrass (Posidonia oceanica) shoot population dynamics along the Spanish Mediterranean. Estuaries 28:53-62

> Martínez-Lüscher J, Holmer M (2010) Potential effects of the invasive species Gracilaria vermiculophylla on Zostera marina metabolism and survival. Mar Environ Res 69: 345-349

North WJ (1973) Regulating marine transplantation. Science 179:1181

Norton TA (1977) Ecological experiments with Sargassum muticum. J Mar Biol Assoc UK 57:33-43

Orth RJ, Carruthers TJB, Dennison WC, Duarte CM and others (2006) A global crisis for seagrass ecosystems. BioScience 56:987-996

Parker IM, Rodriguez J, Loik ME (2003) An evolutionary approach to understanding the biology of invasions: local adaptation and general-purpose genotypes in the weed Verbascum thapsus. Conserv Biol 17:59-72

Ribera MA, Boudouresque CF (1995) Introduced marine plants, with special reference to macroalgae: mechanisms and impact. Prog Phycol Res 11:187-268

Scagel RF (1956) Introduction of a Japanese alga, Sargassum muticum, into the Northeast Pacific. Fish Res Pap Wash Dep Fish 1:1-10

Scagel RF (1973) Marine benthic plants in the vicinity of Bamfield, Barkley Sound, British Columbia. Syesis 6:127-145

Short FT, Wyllie-Echeverria S (1996) Natural and humaninduced disturbance of seagrasses. Environ Conserv 23: $17-27$

- Shurin JB (2000) Dispersal limitation, invasion resistance, and the structure of pond zooplankton communities. Ecology 81:3074-3086

Stachowicz JJ, Fried H, Osman RW, Whitlatch RB (2002) Biodiversity, invasion resistance, and marine ecosystem function: reconciling pattern and process. Ecology 83: $2575-2590$

Strong JA, Dring MJ, Maggs CA (2006) Colonisation and modification of soft substratum habitats by the invasive macroalga Sargassum muticum. Mar Ecol Prog Ser 321: 87-97

Thom RM, Hallum L (1990) Long-term changes in the areal extent of tidal marshes, eelgrass meadows and kelp forests 
of Puget Sound. Final report to Office of Puget Sound, Region 10, U.S. EPA. University of Washington Fisheries Research Institute, Seattle, WA

Thomsen MS, Wernberg T, Stæhr PA, Pedersen MF (2006) Spatio-temporal distribution patterns of the invasive macroalga Sargassum muticum within a Danish Sargassum bed. Helgol Mar Res 60:50-58

Tweedley JR, Jackson EL, Attrill MJ (2008) Zostera marina seagrass beds enhance the attachment of the invasive alga Sargassum muticum in soft sediments. Mar Ecol Prog Ser 354:305-309

Walker DI, Kendrick GA, McComb AJ (2006) Decline and recovery of seagrass ecosystems - the dynamics of change. In: Larkum AWD, Orth RJ, Duarte CM (eds) Seagrasses: biology, ecology and conservation. Springer, Dordrecht, p 551-565

White LF, Shurin JB (2007) Diversity effects on invasion vary with life history stage in marine macroalgae. Oikos 116:

Editorial responsibility: Hans Heinrich Janssen, Oldendorf/Luhe, Germany
$1193-1203$

Williams SL (2007) Introduced species in seagrass ecosystems: status and concerns. J Exp Mar Biol Ecol 350: 89-110

Williamson KJ (2006) Relationships between eelgrass (Zostera marina) habitat characteristics and juvenile Dungeness crab (Cancer magister) and other invertebrates in southern Humboldt Bay, California. MS thesis, Humboldt State University, Arcata, CA

Withers RG, Farnham WF, Lewey S, Jephson NA, Haythorn JM, Gray PWG (1975) The epibonts of Sargassum muticum in British waters. Mar Biol 31:79-86

Wonham MJ, Carlton JT (2005) Trends in marine biological invasions at local and regional scales: the Northeast Pacific Ocean as a model system. Biol Invasions 7:369-392

> Wonham M, O'Connor M, Harley CDG (2005) Positive effects of a dominant invader on introduced and native mudflat species. Mar Ecol Prog Ser 289:109-116

Submitted: May 15, 2009; Accepted: November 25, 2010 Proofs received from author(s): February 4, 2011 